\title{
Elizabethkingia Meningoseptica'ya Bağlı Bir Neonatal Bakteriyemi Olgusu
}

\author{
Elizabethkingia Meningoseptica’ya Bağhl Bir Neonatal Bakteriyemi Olgusu
}

${ }^{1}$ Filiz Orak, ${ }^{2}$ Sadık Yurttutan, ${ }^{1}$ Mehmet İlker Tosun, ${ }^{3}$ İbrahim Seyfettin Çelik, ${ }^{4}$ Süreyya Kurt

'Kahramanmaras Sütçü İmam Üniversitesi Tip Fakültesi, Tibbi Mikrobiyoloji Anabilim Dalı, Kahramanmaraş, Turkey

${ }^{2}$ Kahramanmaraş Sütçü İmam Üniversitesi Tip Fakültesi, Neonatoloji Bilim Dalı, Kahramanmaraş, Turkey

${ }^{3}$ Kahramanmaraş Sütçü İmam Üniversitesi, Üniversite - Sanayi - Kamu İsbirliği Geliștirme, Uygulama ve Araștırma Merkezi (ÜSKIMM)

Kahramanmaraș, Turkey

\section{${ }^{4}$ Kahramanmaras Sütçü İmam}

Üniversitesi, Sağlık Bilimleri Enstitüsü, Kahramanmaraş, Turkey

\section{Correspondence:}

Mehmet İlker TOSUN

Kahramanmaraş Sütçü İmam

Üniversitesi Tip Fakültesi, Tibb

Mikrobiyoloji Anabilim Dalı,

Kahramanmaraş, Turkey

e-mail: ilkertosun1991@gmail.com

\section{Özet}

Elizabethkingia meningoseptica (Chryseobacterium meningosepticum) is a rare nosocomial infection that can show multiple antimicrobial resistance. It has been shown to cause epidemics in neonatal units. This case is presented to discuss this rare cause of Elizabethkingia meningoseptica growth in the blood culture of a patient followed in the neonatal intensive care unit due to asphyxia and hypothermia. This case was presented because Elizabethkingia meningoseptica was detected in the blood culture of a patient followed in the neonatal intensive care unit due to difficult delivery and asphyxia, and the patient was successfully treated with vancomycin

Anahtar Kelimeler: Elizabethkingia meningoseptica; bacteremia; infection; neonatal

\section{Abstract}

Elizabethkingia meningoseptica (Chryseobacterium meningosepticum), nadir görülen ve çoklu antimikrobiyal direnci görülebilen bir hastane enfeksiyonu etkenidir. Yenidoğan ünitelerinde salgınlara yol açtığı gösterilmiștir. Bu olgu, zor doğum ve asfiksi nedeniyle yenidoğan yoğun bakım ünitesinde takip edilen bir hastanın kan kültüründe Elizabethkingia meningoseptica'nın saptanması ve hastanın vankomisin ile başarılı bir şekilde tedavi edilmesi nedeniyle sunulmak istenmiştir.

Keywords: Elizabethkingia meningoseptica; bakteriyemi; enfeksiyon; yenidoğan 


\section{Giriș}

Elizabethkingia meningoseptica (E. meningoseptica) glukozu fermente etmeyen, hareketsiz, oksidaz pozitif, Gram negatif aerobik basildir. Önceleri Flavobacterium meningosepticum ve Chryseobacterium meningosepticum olarak adlandırılmıştır(1). Chryseobacterium'un doğal habitatları, hastane florası da dahil olmak üzere toprak, bitkiler, gida maddeleri ve su kaynaklarıdır(2). Birçok E. meningoseptica enfeksiyonu vakası, hastane musluk suyu, dezenfektanlar, salin, antibiyotik solüsyonları, lipid solüsyonu, lavabo drenajları ve solunum ekipmanının kontaminasyonuna bağlı olarak bildirilmiştir(3,4). E. meningoseptica çoklu antimikrobiyale direnç gösterebilmesi ve ciddi enfeksiyonlara yol açması ile gündeme gelmektedir. Özellikle yenidoğan yoğun bakım ünitelerinde bu etkene bağlı sepsis ve menenjit salgınlar1 bildirilmektedir(3). E.meningoseptica, birincil olarak bağışıklı̆g 1 baskılanmış bireyleri enfekte eder ve yüksek mortalite ( $\left(\begin{array}{llll}\sim & 20 & - & 40\end{array}\right)$ ile ilişkilidir(5). Çalışmamızda yenidoğan bir erkek hastada nadir rastlanan $E$. meningoseptica' ya bağlı bir bakteriyemi olgusu sunulmuştur.

\section{Olgu}

Hasta 30 yaşındaki annenin 3. gebeliğinden normal vajinal yol ile 38 haftalık olarak doğmuştur. Doğum ağırlı̆̆ 4600 gram olup zor doğum ve asfiksi öyküsü olan hasta yenidoğan yoğun bakım ünitesine yatırılmış ve entübe olarak takip edilmeye başlanmıştır. Asfiktik durumdaki hasta Sarnat \& Sarnat Sınıflaması'na göre evre I-II kabul edilmiş ve 72 saat boyunca hipotermi tedavisine alınmıştır. Ek olarak sağ kolunda şişlik ve ekimozları bulunan hastanın çekilen direkt radyografisinde sa $\breve{g}$ klavikuler kırı $\breve{g} 1$ tespit edilmiştir. Sağ kol için elevasyon, soğuk uygulama, dolaşım takibi ve Velpau bandajı uygulanmıştır. Hastanın yatışının 3.gününde CRP (C-reaktif protein) değerinin $2 \mathrm{mg} / \mathrm{l}$ 'den $14,5 \mathrm{mg} / \mathrm{l}$ 'ye, prokalsitonin değerinin 0,21 $\mu \mathrm{g} / \mathrm{L}$ 'den $1,29 \quad \mu \mathrm{g} / \mathrm{L}$ 'ye ve beyaz küre sayısının $13500 / \mathrm{mm}^{3}$ 'e yükselmesinin üzerine ampirik olarak vankomisin ve amikasin tedavisi başlanmış ve kan kültürü gönderilmiştir. Kan kültüründe E.meningoseptica tespit edilen hastanın bu süre zarfinda vankomisin ve amikasin tedavisine devam edilmiştir. Antibiyotik tedavisinin 10.gününde lökosit, $\mathrm{CRP}$ ve prokalsitonin değerlerinin normal sınırlara gelmesi üzerine antibiyotik tedavisi kesilmiştir. Takibinde oral alıma geçen ve genel durumu iyi seyreden hasta taburcu edilmiştir.

\section{İolatın tanımlanmast ve antimikrobiyal duyarlılı̆g}

Laboratuvarımıza gelen kan kültürü şişeleri kan kültürü cihazına (BACTEC FX TOP, Becton, Dickinson and Company, ABD(Amerika Birleşik Devletleri) yüklenmiştir. Pozitif sinyal veren örneklerin Gram boyaması yapılmış ve koyun kanlı agar (BD(Becton, Dickinson and Company) Columbia Agar with 5\% Sheep Blood, ABD), çikolata agar (BD Chocolate Agar, GC II Agar with IsoVitaleX, ABD), eosin metilen blue (EMB) agar (BD EMB Agar (Eosin Methylene Blue Agar), Modified,ABD) besiyerlerine ekim yapilarak $37^{\circ} \mathrm{C}^{\prime}$ de 24 saat süre ile inkübe edilmiştir. Gram boyamada Gram-negatif basiller saptanmıştır. İnkübasyon sonunda koyun kanlı agarda küçük, mat ve beyaz koloniler üremiştir (Resim 1). EMB(Eosin Methylene Blue) agarda küçük, laktoz negatif koloniler üremiştir. Üreyen koloniler konvansiyonel yöntemler kullanılarak, oksidaz pozitif, katalaz pozitif, hareketsiz olarak tespit edilmiştir. İzolatın kesin tanısı için otomatize tanımlama ve antimikrobiyal duyarlılık sistemi (BD Phoenix 100, Becton, Dickinson and Company, ABD) kullanılmıştır (Tablo1). Antimikrobiyal sonuçların duyarlılık tespiti için The European Committee on Antimicrobial Susceptibility Testing (EUCAST) k1lavuzunda non fermenter bakteriler için tanımlanan kriterler kullanılmıştır (6). 


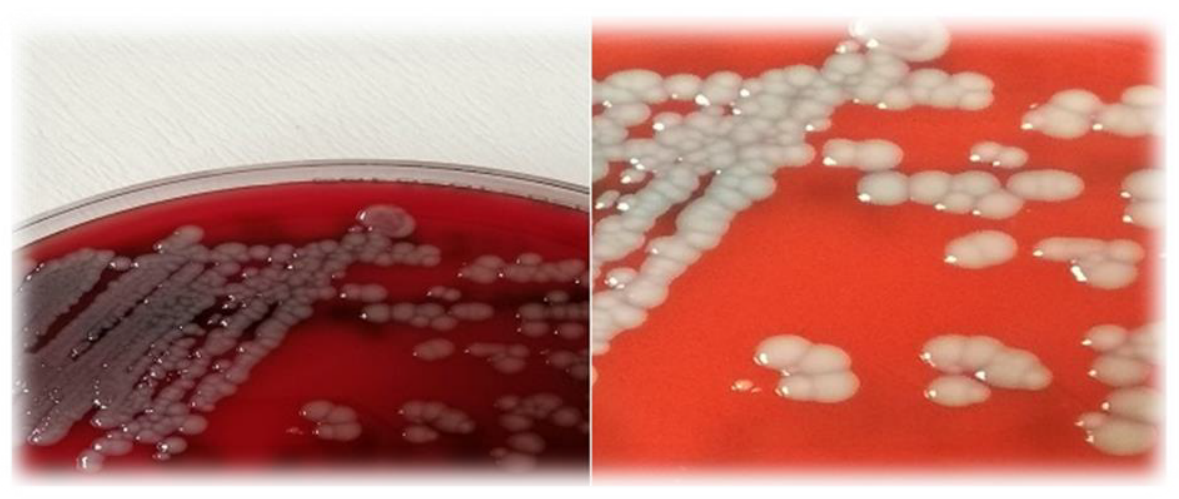

Resim 1. Koyun kanlı agarda E. Meningoseseptica kolonileri

Tablo 1. E. meningoseptica'nın antimikrobiyal duyarlılığ

\begin{tabular}{ll}
\hline Antimikrobiyal madde & Sonuç / MİK $(\mu \mathrm{g} / \mathrm{ml})$ \\
\hline Amikasin & Dir ençli $(>32)$ \\
Kolistin & Dirençli $(>4)$ \\
Gentamisin & Dirençli $(>8)$ \\
İmipenem & Dirençli $(>8)$ \\
Meropenem & Dirençli $(>8)$ \\
Levofloksasin & Duyarlı $(1)$ \\
Siprofloksasin & Dirençli $(>1)$ \\
Piperasilin/tazobaktam & Duyarlı $(<=4 / 4)$ \\
Sefepim & Dirençli $(>8)$ \\
Seftazidim & Dirençli $(>8)$ \\
\hline MIK: minimum inhibitör konsantrasyon &
\end{tabular}

Kültürden izole edilen E. meningoseptica'nın moleküler tanımlaması için BAK2(5'GGACTACHAGGGTATCTAAT3') ve BAK11(3'AGTTTGATCMTGGCTCAG5') primerleri kullanılarak 16S rRNA(Ribozomal Ribonükleik Asit) PCR(Polimeraz zincir reaksiyonu) yöntemi uygulanmıştır. Sanger sekanslama analizi (Applied Biosystem 3130 Genetic Analyzer, Applied Biosystems, Fisher Scientific, Waltham, MA, ABD) ile nükleotid dizisi belirlenmiştir. Sekans sonuçları BLAST (Basic Local Alignment Search Tool) programında analiz edilmiştir. İzole edilen $E$. meningoseptica'ya ait nükleotid dizisi GenBankaKSU-Cifo adiyla ve MZ221765 aksesyon numarasıyla kaydedilmiştir (7).

Çalışmamız Etik Kurul Komitesinin 05.04.2021 tarihli, Karar No:10 ve Oturum:2021/13 ile onaylanmıştır. Çalışmaya dahil edilen hastanın ebeveyni tarafindan bilgilendirilmiş onam formu imzalanmıştır.

\section{Tartışma ve Sonuç}

E. meningoseptica hastane ortamında entübasyon tüplerini ve solunum cihazlarını kontamine edebilmektedir. Hastanede entübe olarak yatmakta olan özellikle yenidoğan ve bağışıklığ 1 baskılanmış hasta gruplarında nadir ama ciddi bir enfeksiyon etkenidir $(1,8)$. Tekerekoğlu ve ark. tarafindan yapılan bir çalışmada, yenidoğan yoğun bakım ünitesinde meydana gelen bir salginda intravenöz beslenme sıvilarının enfeksiyon kaynağ olduğu belirtilmiştir(3). Nadir bir hastane enfeksiyonu etkeni olmakla birlikte özellikle son on yılda $E$. meningoseptica'ya bağlı nozokomiyal enfeksiyonlarda artış tespit edilmiştir (9). E.meningoseptica'nın bulaş yolu, virülans faktörleri, etkili tedavi rejimleri ve antimikrobiyal direnç paternleri hakkında henüz yeterli bilgi bulunmamaktadır(8). Bundan ötürü E. meningoseptica'nın yol açtığı enfeksiyonların halen yüksek mortaliteye (\%20-40) neden olduğu belirtilmektedir(10). 
E.meningoseptica'nın yenidoğan yoğun bakım ünitelerinde sepsis ve menenjit salgınlarına yol açtığı bilinmekte olup, risk faktörleri arasında çoklu komorbiditeye sahip olma, immunsüpresyon, ventilatör desteği, prematürite yer almaktadır(11). Olgumuzdaki hasta asfiksi ve zor doğum gibi komorbiditeleri bulunup klinik durumu nedeniyle entübe edilmiştir. Hastanın kan kültüründen $E$. meningoseptica izole edilmesinde bu faktörlerin de etkili olduğu düşünülmektedir.

E. meningoseptica'nın çoklu ilaç direncine sahip olması nedeniyle, tedavi planında mutlaka antimikrobiyal duyarlılık sonuçları göz önüne alınmalıdır. Tedavide florokinolonlar, trimetoprim-sülfametoksazol, minosiklin, piperasilin-tazobaktam gibi seçenekler bulunmaktadır(10). Aminoglikozit grubu antibiyotikler, karbapenemler ve kolistin gibi antimikrobiyaller ise tedavide daha az etkilidir(12). Olgumuzda izole edilen suş kolistin, gentamisin, imipenem ve meropeneme dirençli; levofloksasin ve piperasilin-tazobaktama duyarlı bulunmuștur. E. meningoseptica Gram negatif bir etken olmakla birlikte vankomisin ile $E$. meningoseptica tedavisinde başarılı

\section{KAYNAKLAR}

1. Schreckenberger, Paul C. "Acinetobacter, Achomobacter, Chryseobacterium, Moraxella and other non-fermentative Gram-negative rods." Manual of Clinical Microbiology. 2003; 754-57.

2. Vandamme, Peter, et al. New Perspectives in the Classification of the Flavobacteria: Description of Chryseobacterium gen. nov., Bergeyella gen. nov., and Empedobacter nom. rev. International Journal of Systematic and Evolutionary Microbiology, 1994; 44: 827-31.

3. Tekerekoglu, M. S., et al. Analysis of an outbreak due to Chryseobacterium meningosepticum in a neonatal intensive care unit. The New Microbiologica, 2003; 26: 57-63.

4. Hoque, S. N. Graham, J., Kaufmann, M. E., Tabaqchali, S. Shryseobacterium (Flavobacterium) meningosepticum outbreak associated with colonization of water taps in a neonatal intensive care unit. Journal of Hospital Infection, 2001;47, 188-92.

5. Burnard, Delaney, et al. Comparative genomics and antimicrobial resistance profiling of olunduğuna dair çalışmalar da mevcuttur(2,13). Olgumuzda hastaya ampirik olarak başlanan vankomisin tedavisinin sonucunda hastanın kliniğinde ve laboratuvar parametrelerinde belirgin düzelme olması bu çalışmalarla uyumlu niteliktedir.

Sonuç olarak, E. meningoseptica'nın nemli ve sslak ortamlarla temas sonucu hastane kaynaklı enfeksiyonlara neden olduğu bilinmektedir. Bundan dolayı hastanelerde entübasyon, kateterizasyon gibi girişimsel işlemlerde ve ventilasyon gibi tıbbi cihazların kullanımında gerekli dezenfeksiyon kurallarına uyulması önemlidir. Nadir görülmekle birlikte bağışıklığı baskılanmış hastalar ve yenidoğanlarda, ampirik antibiyotik tedavisine cevap vermeyen ciddi enfeksiyonlarda, Gram negatif basil izole edildiğinde E.meningoseptica da akla getirilmelidir. Böylelikle bakterinin hılı bir şekilde tanımlanması ve antibiyogram sonuçlarına uygun şekilde tedavisi mümkün olacak, yüksek morbidite ve mortalite önlenebilecektir.
Elizabethkingia isolates reveal nosocomial transmission and in vitro susceptibility to fluoroquinolones, tetracyclines, and trimethoprimsulfamethoxazole. Journal of Clinical Microbiology, 2020; 58: e00730-20.

6. "The European Committee on Antimicrobial Susceptibility Testing. Breakpoint tables for interpretation of MICs and zone diameters. Version 11.0, 2021. http://www.eucast.org."

7. (https://www.ncbi.nlm.nih.gov/nucleotide/MZ221 765.1 ?report $=$ genbank\& $\log \$=$ nucltop\&blast_rank $=40 \&$ RID $=$ D90G62NN013).

8. Jean, S. S., et al. Elizabethkingia meningoseptica: an important emerging pathogen causing healthcare-associated infections. Journal of Hospital Infection, 2014; 86: 244-49.

9. PANETTA, Vittorio, et al. Elizabethkingia meningosepticum: an emerging nosocomial pathogen in a critical patient with septicaemia. Microbiologia Medica, 2017; 32.

10. HSU, M.-S., et al. Clinical features, antimicrobial susceptibilities, and outcomes of Elizabethkingia 
meningoseptica (Chryseobacterium meningosepticum) bacteremia at a medical center in Taiwan, 1999-2006. European Journal of Clinical Microbiology \& Infectious Diseases, 2011; 30: 1271-78.

11. da Silva, P. S. L., \& Pereira, G. H. Elizabethkingia meningoseptica: emergent bacteria causing pneumonia in a critically ill child. Pediatrics International , 2013; 55, 231-34.

12. Kirby, Jeffrey $T$., et al. Antimicrobial susceptibility and epidemiology of a worldwide collection of Chryseobacterium spp.: report from the SENTRY Antimicrobial Surveillance Program (1997-2001). Journal of Clinical Microbiology, 2004; 42: 445-48.

13. Güngör, Serdal, et al. A Chryseobacterium meningosepticum outbreak in a neonatal ward. Infection Control \& Hospital Epidemiology, 2003; 24: 6;13-17. 